\title{
Management of Patients With Unprovoked Venous Thromboembolism: An Evidence-Based and Practical Approach
}

Maura Marcucci, MD

Alfonso Iorio, MD, MSC James Douketis, MD, FRCPC ${ }^{*}$

\author{
Address \\ *Departments of Medicine and Clinical Epidemiology and Biostatistics, \\ McMaster University, St. Joseph's Healthcare, F-544, 50 Charlton Ave East, \\ Hamilton, 0N, Canada L8N 4A6 \\ Email: jdouket@mcmaster.ca
}

Published online: 24 January 2013

(C) The Author(s) 2013. This article is published with open access at Springerlink.com

Keywords Venous thromboembolism • Unprovoked • Extended anticoagulation - Risk factors •

Inherited thrombophilia · Residual vein occlusion - D-Dimer · Clinical prediction guide

\section{Opinion statement}

The management of patients with unprovoked venous thromboembolism is a common and challenging clinical problem. Although the initial antithrombotic management is well-established, there is uncertainty about the optimal long-term anticoagulant management, specifically whether patients should receive a short (i.e., 3- to 6-month) duration of anticoagulant therapy or indefinite anticoagulation. Factors that may be considered to estimate patients' risk for recurrent thromboembolism include the mode of initial clinical presentation, as deep vein thrombosis or pulmonary embolism, patient sex, antecedent hormonal therapy use, thrombophilia, D-dimer levels, and residual vein occlusion in patients with deep vein thrombosis. Many of these factors have been integrated into clinical prediction guides which stratify patients with unprovoked venous thromboembolism according to their risk for disease recurrence and, thereby, can assist clinicians in decisions about the duration of anticoagulation. The objective of this review is to consider the evidence relating to the clinical significance of purported risk factors and provide a practical case-based approach to guide decisions on duration of anticoagulation for patients with unprovoked venous thromboembolism. 


\section{Introduction}

The management of patients with venous thromboembolism (VTE) should reflect the biphasic, acute and chronic, nature of this disease $[1 \bullet]$. In the acute phase, the overall treatment aim is to reduce symptoms related to deep vein thrombosis (DVT) and pulmonary embolism (PE) and to prevent thrombus extension and (additional) embolization, the latter of which can increase mortality [2-4]. This can be done with prompt initiation of anticoagulant therapy $[5 \bullet \bullet]$. The initial phase of anticoagulation aims also to prevent extension of asymptomatic DVT, which occurs in $20 \%$ of patients presenting with symptomatic PE alone, and to prevent recurrent $\mathrm{PE}$, which is present but silent in up to $50 \%$ of patients presenting with DVT alone [6]. Minimizing the risk for DVT progression or recurrent PE is important to mitigate the risk that patients will develop the post-thrombotic syndrome [7] and chronic thromboembolic pulmonary hypertension [8], and to prevent recurrent VTE that is fatal.

After this initial treatment, the aim of anticoagulant therapy is to minimize the risk for disease recurrence since the occurrence of a first VTE markedly increases the risk for further VTE [6,9]. Vitamin K antagonist therapy, typically with warfarin, is highly effective in reducing the risk for recurrent VTE $[10,11]$. Although this clinical benefit is not maintained after treatment discontinuation, regardless of its duration $[11,12,13 \bullet \bullet]$, the benefit of continued anticoagulation needs to be balanced against the risk for anticoagulant-related bleeding [14]. Given the effectiveness of anticoagulants to prevent recurrent VTE (as summarized in Table 1), the challenge facing the clinician is to identify which patients would derive a net clinical benefit from indefinite anticoagulant therapy and those in whom avoidance of long-term anticoagulation is preferable.

It is widely accepted that three months of anticoagulation is sufficient for most patients with a first VTE that occurs in association with a major transient risk factor such as surgery, lower limb fracture or other trauma, pregnancy, and immobilization $[5 \bullet \bullet, 15 \bullet \bullet]$. For these patients, the risk of recurrent VTE after three months of anticoagulation is lower compared with a shorter duration of treatment but there is no therapeu-

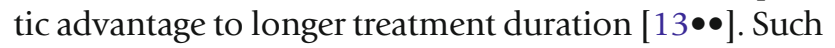
patients have a good prognosis, with a $1-3 \%$ person-

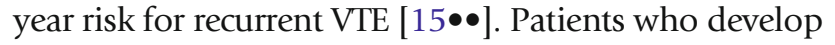

VTE in association with a weak risk factor, such as estrogen use or long-distance travel, appear to have a slightly

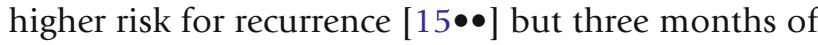
anticoagulation also is sufficient in such patients. Finally, patients who develop VTE in association with active cancer warrant consideration for indefinite anticoagulation $[5 \bullet \bullet]$.

In contrast, there is uncertainty about optimal management for patients with unprovoked VTE, who comprise approximately $50 \%$ of all patients with a first VTE. In such patients who have received three months of anticoagulation, the risk for recurrent VTE is $5-15 \%$ per year after anticoagulation is stopped $[15 \bullet \bullet, 16 \bullet]$, or up to $30-35 \%$ after five years $[16 \bullet, 17 \bullet \bullet, 18]$, and this recurrence risk is not affected by whether patients receive an additional 3-9 months

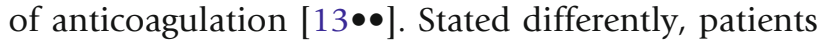
with unprovoked VTE who are destined to develop disease recurrence will do so irrespective of the duration of anticoagulation. When considered against a 1-3 \% annual risk for anticoagulant-related bleeding [14], the net therapeutic benefit would seem to favor administering indefinite anticoagulation in all patients with unprovoked VTE. However, rather than subject all such patients to the risks and costs of indefinite anticoagulation, the challenge for the clinician is to identify patients who are most likely to develop recurrent VTE, in whom indefinite anticoagulation can be justified, and those patients with an acceptably low risk for recurrence in whom anticoagulation can be stopped.

Against this background, the objectives of this review are: 1) to summarize, risk factors and clinical prediction guides (CPGs) that can be used to estimate patients' risk for recurrence after a first unprovoked VTE; and 2) to suggest a management strategy to help guide decisions of whether to recommend 3-6 months or indefinite anticoagulation in such patients. Three representative case vignettes will be considered to help illustrate the suggested clinical approach:

- 58 year old man, otherwise well, with a first unprovoked PE (D-dimer not available);

- 35 year old woman, otherwise well, with a first PE occurring during oral contraceptive use;

- 82 year old woman, with co-morbidities, and a first unprovoked DVT (D-dimer available) 
Table 1. Pharmacologic treatment options

\begin{tabular}{|c|c|c|c|}
\hline Drug [ref] ${ }^{\ddagger}$ & $\begin{array}{l}\text { Standard dosage and timing } \\
\text { Acute phase treatment }\end{array}$ & $\begin{array}{l}\text { Long-term } \\
\text { and extended* } \\
\text { treatment }\end{array}$ & Comments \\
\hline $\begin{array}{l}\text { Unfractionated } \\
\text { heparin (UFH) } \\
{[5 \bullet \bullet, 95]}\end{array}$ & $\begin{array}{l}80 \mathrm{U} / \mathrm{kg} \text { bolus i.v., then } 18 \mathrm{U} / \mathrm{kg} / \mathrm{h} \\
\text { (or 5,000 U i.v. then } 1000 \mathrm{U} / \mathrm{h} \text { ), } \\
\text { adjusting infusion velocity to reach a } \\
\text { PTा target 1.5-2.5 times normal }\end{array}$ & - & $\begin{array}{l}\text { When thrombolytic therapy is planned, UFH is } \\
\text { recommended over LMWH or fondaparinux } \\
\text { for the acute phase treatment. }\end{array}$ \\
\hline $\begin{array}{l}\text { Low-molecular- } \\
\text { weight heparin } \\
(\text { LMWH) } \\
{[5 \bullet \bullet, 95,96]}\end{array}$ & $\begin{array}{l}\text { Enoxaparin: } 1 \mathrm{mg} / \mathrm{kg} \text { s.c. twice a day } \\
\text { Enoxaparin: } 1.5 \mathrm{mg} / \mathrm{kg} \text { s.c. once daily } \\
\text { Tinzaparin: } 175 \mathrm{U} / \mathrm{kg} \text { s.c. once daily } \\
\text { Dalteparin: } 200 \mathrm{U} / \mathrm{kg} \text { s.c. once daily }\end{array}$ & & $\begin{array}{l}\text { 1. Long-term ( } 6 \text { months) treatment with heparin } \\
(1 \text { month of full dose followed by } 5 \text { months of } \\
\text { reduced dose to } 75 \% \text { ) was demonstrated to be } \\
\text { more effective than warfarin only in patient } \\
\text { with VTE and cancer. } \\
\text { 2. If renal impairment (calculated creatinine } \\
\text { clearance }<30 \mathrm{ml} / \mathrm{min} \text { ), consider UFH. }\end{array}$ \\
\hline $\begin{array}{l}\text { Fondaparinux } \\
{[5 \bullet \bullet, 95]}\end{array}$ & $\begin{array}{l}7.5 \mathrm{mg} \text { s.c. once daily (or } 5 \mathrm{mg} \text { once } \\
\text { daily if body weight }<50 \mathrm{~kg} ; 10 \mathrm{mg} \\
\text { once daily if }<\text { if body weight }>100 \mathrm{mg} \text { ) }\end{array}$ & - & No evidence for long-term/extended treatment \\
\hline $\begin{array}{l}\text { Systemic } \\
\text { thrombolysis } \\
{[5 \bullet \bullet]}\end{array}$ & Recombinant t-PA $100 \mathrm{mg}$ i.v. over $2 \mathrm{~h}$ & - & Patients with PE associated with hypotension \\
\hline $\begin{array}{l}\text { Vitamin K } \\
\text { Antagonist } \\
{[5 \bullet \bullet, 95]}\end{array}$ & $\begin{array}{l}\text { Warfarin: loading dose of } 5 \text { or } 10 \mathrm{mg} \\
\text { for first } 2 \text { days then dosing based } \\
\text { on INR (target } 2.5 \text {, range } 2-3 \text { ) }\end{array}$ & $\begin{array}{l}\text { Continue warfarin } \\
\text { dose based on } \\
\text { INR monitoring }\end{array}$ & $\begin{array}{l}\text { 1. In patients with acute VTE, warfarin should } \\
\text { be started early together with parenteral } \\
\text { anticoagulation which should be given for at } \\
\text { least } 5 \text { days while waiting for therapeutic INR } \\
\text { 2. Low-intensity warfarin (target } 1.5-2 \text { ) after a } \\
\text { first full-dose treatment (for at least } \\
3 \text { months) may reduce recurrences but is less } \\
\text { effective than full-dose warfarin }\end{array}$ \\
\hline $\begin{array}{l}\text { Rivaroxaban } \\
{[5 \bullet \bullet, 97,98]}\end{array}$ & $\begin{array}{l}15 \mathrm{mg} \text { orally twice a day for } 3 \text { weeks } \\
\text { and then } 20 \mathrm{mg} \text { once daily }\end{array}$ & $20 \mathrm{mg}$ once daily & $\begin{array}{l}\text { In patients who receive rivaroxaban for } \\
\text { acute VTE, there is no requirement for } \\
\text { initial treatment with UFH or CMWH }\end{array}$ \\
\hline $\begin{array}{c}\text { Dabigatran } \\
{[5 \bullet \bullet, 99]}\end{array}$ & $150 \mathrm{mg}$ orally twice a day & $150 \mathrm{mg}$ twice a day & $\begin{array}{l}\text { 1. In the acute phase, dabigatran should be } \\
\text { started after/in association to an initial } \\
\text { treatment with LMWH or UFH for the first few } \\
\text { days after diagnosis 2. No evidence on } \\
\text { long-term/extended anticoagulation (no more } \\
\text { than } 6 \text { months) with dabigatran for VTE. }\end{array}$ \\
\hline $\begin{array}{l}\text { Aspirin } \\
{[93,94 \bullet \bullet]}\end{array}$ & - & $\begin{array}{l}100 \mathrm{mg} \text { orally } \\
\text { once daily }\end{array}$ & $\begin{array}{l}\text { Possible option in patients not at high risk } \\
\text { of recurrence }\end{array}$ \\
\hline
\end{tabular}

In Table 2 and Fig. 1 we provide a suggested on the available evidence and practical consideraapproach to the management of these cases based tions. 


\begin{tabular}{|c|c|c|c|}
\hline $\begin{array}{l}\text { Case } \\
\text { examples }^{\ddagger}\end{array}$ & $\begin{array}{l}\text { Relevant evidence on } \\
\text { predictors of risk of } \\
\text { recurrence }\end{array}$ & $\begin{array}{l}\text { Recurrent risk estimates } \\
\text { (annualized risk [AR] or } \\
\text { cumulative rate [CR]) } \\
\text { according to available CPGs }\end{array}$ & Conclusion and notes \\
\hline $\begin{array}{l}58 \text { year old man, } \\
\text { first unprovoked } \\
\text { PE (D-dimer }\end{array}$ & $\begin{array}{l}\text { Male sex: } 1.5-2 \text { fold higher risk } \\
\text { compare to females } \\
{[16 \bullet \bullet, 20,22,23 \bullet \bullet, 24-28]}\end{array}$ & $\begin{array}{l}\text { Men and HER-D00-2 [82]: } \\
\text { AR }>3 \%\end{array}$ & High risk patient \\
\hline not available) & $\begin{array}{l}\text { PE as first presentation: } \\
\text { higher risk compared to } \\
\text { distal DVT; no significant } \\
\text { difference compared with } \\
\text { proximal DVT }[12,13 \bullet \bullet, \\
30 \bullet, 31-33] \text {; patients } \\
\text { presenting initially with PE } \\
\text { more likely to have } \\
\text { recurrence as PE than DVT } \\
{[12,30 \bullet, 33,87]}\end{array}$ & $\begin{array}{l}\text { Vienna }[17 \bullet \bullet]: \text { if D-dimer } \\
\text { was available, the opposite } \\
\text { scenario would be: }\end{array}$ & $\begin{array}{l}\text { Note: } 1 . \text { Measuring D-dimer level } \\
\text { would help but this is a high risk } \\
\text { case independently of D-dimer. } \\
\text { 2. If the same patient had } \\
\text { presented with a first proximal } \\
\text { DVT, his risk predicted by Men } \\
\text { and HER-D00-2 and DASH score } \\
\text { would not change and would } \\
\text { decrease slightly with the } \\
\text { Vienna CPG }\end{array}$ \\
\hline & $\begin{array}{l}\text { Age: not definitive } \\
\quad \text { evidence }[16 \bullet \bullet, 17 \bullet \bullet, 84 \bullet \bullet]\end{array}$ & 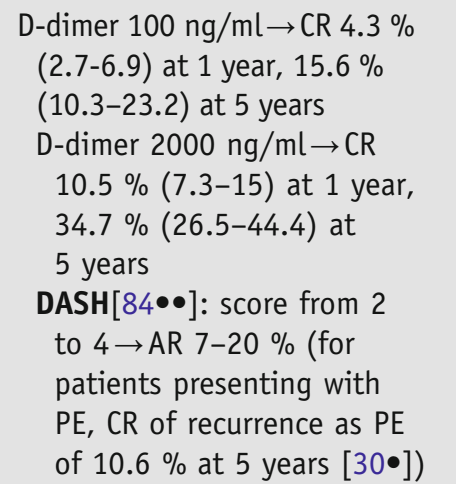 & \\
\hline $\begin{array}{l}35 \text { year old woman, } \\
\text { first PE occurring } \\
\text { during oral } \\
\text { contraceptive } \\
\text { (later stopped) }\end{array}$ & $\begin{array}{l}\text { Women with a hormone- } \\
\text { related VTE: a lower } \\
\text { (nearly } 0.5 \text { ) risk compared } \\
\text { to women with a first } \\
\text { unprovoked not-hormone- } \\
\text { related VTE, if exposure } \\
\text { to hormone therapy risk } \\
\text { comparable to VTE provoked } \\
\text { by nonsurgical transient risk } \\
\text { factor }[15 \bullet \bullet, 16 \bullet \bullet, 21,22,23 \bullet \bullet]\end{array}$ & $\begin{array}{l}\text { Men and HER-D00-2 [82]: } \\
\text { AR }>\text { or }<3 \% \text { depending on } \\
\text { presence or not of at least } 2 \\
\text { of: obesity, signs of } \\
\text { post-thrombotic syndrome, } \\
\text { D-dimer } \geq 250 \mathrm{mg} / \mathrm{dl} \text { [the } \\
\text { estimate of AR for women } \\
\text { with an OC-related VTE at } \\
\text { high risk according to the } \\
\text { score was largely imprecise: } \\
4.1 \%(0-12.2) \text { ] [100] } \\
\text { Vienna }[17 \bullet \bullet] \text { not applicable } \\
\text { DASH }[84 \bullet \bullet] \text { score from }-2 \text { to } \\
0 \rightarrow \text { AR }<3 \%\end{array}$ & Low risk patient \\
\hline
\end{tabular}


Table 2. Case Examples and Suggested Management (Continued)

\begin{tabular}{|c|c|c|c|}
\hline $\begin{array}{l}\text { Case } \\
\text { examples }\end{array}$ & $\begin{array}{l}\text { Relevant evidence on } \\
\text { predictors of risk of } \\
\text { recurrence }\end{array}$ & $\begin{array}{l}\text { Recurrent risk estimates } \\
\text { (annualized risk }[A R] \text { or } \\
\text { cumulative rate [CR]) } \\
\text { according to available CPGs }\end{array}$ & Conclusion and notes \\
\hline \multirow[t]{4}{*}{$\begin{array}{l}82 \text { year old } \\
\text { woman, with } \\
\text { co-morbidities, } \\
\text { first unprvoked } \\
\text { proximal DVT } \\
\text { (D-dimer } \\
\text { available) }\end{array}$} & $\begin{array}{l}\text { Female sex: } 2-1.5 \text {-fold } \\
\text { lower risk compare to } \\
\text { males }[16 \bullet \bullet, 20,22 \text {, } \\
23 \bullet \bullet, 24-28]\end{array}$ & $\begin{array}{l}\text { Men and HER-DOO-2 [82]: } 1 \\
\text { point for age } \rightarrow A R>\text { or }<3 \% \\
\text { depending on presence or not } \\
\text { of at least } 1 \text { of: obesity, signs } \\
\text { of post-thrombotic syndrome, } \\
\text { D-dimer } \geq 250 \mathrm{mg} / \mathrm{dl}\end{array}$ & Intermediate risk patient \\
\hline & $\begin{array}{l}\text { Proximal DVT as first } \\
\text { presentation: a higher risk } \\
\text { compared to distal DVT; } \\
\text { probably not significant } \\
\text { difference respect to PE } \\
{[12,13 \bullet \bullet, 30 \bullet, 31-33]}\end{array}$ & $\begin{array}{l}\text { Vienna }[17 \bullet \bullet] \text { : CR range } \\
\text { according to D-dimer level: }\end{array}$ & \multirow{3}{*}{$\begin{array}{l}\text { Note: Although the prognostic } \\
\text { validity of D-dimer holds } \\
\text { regardless of patient comorbiity, } \\
\text { the presence of multimorbidity } \\
\text { affects the decision process since } \\
\text { a) it can increases the patient risk } \\
\text { of bleeding; b) the decision on } \\
\text { extended anticoagulation may } \\
\text { cross other therapeutic needs }\end{array}$} \\
\hline & $\begin{array}{l}\text { Age: not definitive evidences } \\
{[16 \bullet \bullet, 17 \bullet \bullet, 84 \bullet \bullet]}\end{array}$ & $\begin{array}{l}\text { D-dimer } 100 \mathrm{ng} / \mathrm{ml} \rightarrow \mathrm{CR} \\
2.0 \%(1.1-3.7) \text { at } 1 \text { year, } \\
7.6 \%(4.3-13.3) \text { at } 5 \text { years }\end{array}$ & \\
\hline & $\begin{array}{l}\text { D-dimer after stopping } \\
\text { anticoagulation: strong } \\
\text { predictor of risk independent } \\
\text { of age and comorbidity } \\
{[16 \bullet \bullet, 65-73]}\end{array}$ & $\begin{array}{l}\text { D-dimer } 2000 \mathrm{ng} / \mathrm{ml} \rightarrow 5.1 \% \\
(3.3-7.8) \text { at } 1 \text { year, } 18.1 \% \\
(12.5-25.8) \text { at } 5 \text { years } \\
\text { DASH [85]: score from } \\
1 \text { to } 3 \text { according to } \\
\text { D-dimer level } \rightarrow \text { AR 2.9- } \\
13.4 \%\end{array}$ & \\
\hline
\end{tabular}

\section{Clinical and laboratory risk factors for recurrent VTE}

Treatment guidelines such as the 2012 American College of Chest Physi-

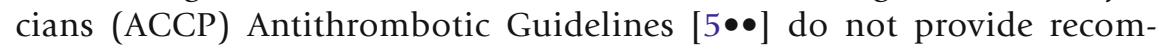
mendations for using risk factors or CPGs to decide on the duration of anticoagulation for individual patients after unprovoked VTE, though it is suggested that these factors be considered in the decision-making process $[5 \bullet \bullet$. Herein, we shall review factors for which there is a clinically meaningful body of evidence regarding their role in estimating the risk of recurrent VTE whereas other clinical factors, such as age and obesity, and other laboratory markers, for which there is a paucity of evidence, will not be reviewed. 


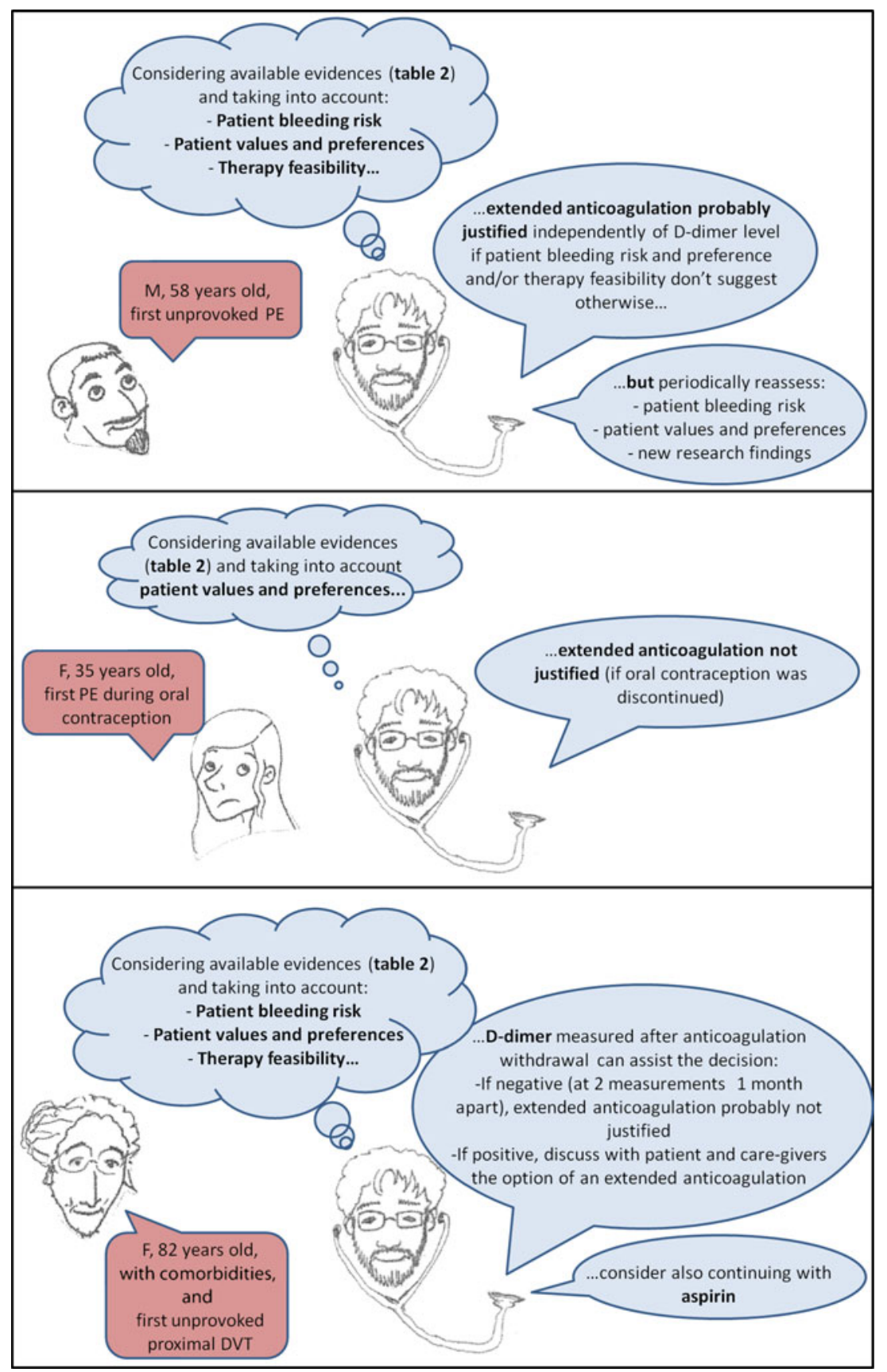

Fig. 1. Case examples: suggested strategies for a long-term management. Legend. The vignette synthesizes the suggested treatment strategies for the clinical cases proposed as example of patients at high, low and intermediate risk, joining the evidence summarized in Table 2 with other relevant aspects of the clinical decision making process. (Thanks to Nebbiai Mattia for the drawing).

\section{Estrogens and patient gender}

High levels of estrogen, whether occurring during pregnancy and the puerperium or with oral contraceptive or estrogen replacement therapy use, increase 
the risk for VTE [19]. Women who continue hormonal therapy after a hormone-related VTE have a 5 -fold increased risk of recurrent VTE [20]. Conversely, women who stop hormonal therapy after VTE have a $50 \%$ lower risk for recurrence than women with unprovoked (not hormone-related) VTE $[15 \bullet \bullet, 16 \bullet, 21,22,23 \bullet \bullet]$. From an absolute risk perspective, women who stop hormonal therapy after VTE have an approximately $4 \%$ annual risk of disease recurrence, which is slightly higher than after surgery-related VTE but similar to the recurrence risk when VTE occurs in association with non-surgical transient risks such as immobilization or long-distance travel $[15 \bullet \bullet, 21]$. Estrogen exposure may also explain the observed difference in the risk for recurrent VTE between men and women. After discordant findings reported in individual studies [20,22,24-27], a study-level meta-analysis [28] and a large patient-level meta-analysis $[16 \bullet, 23 \bullet \bullet]$ found that in patients with unprovoked VTE, men had a 1.5-to-2.0-fold higher risk for recurrent VTE than women. Thus, male patients who are treated for three months after a first unprovoked VTE have a 3-year risk of recurrence as high as 20-25\% $[23 \bullet \bullet]$.

\section{Clinical presentation and extent of venous thrombosis}

Although DVT and PE are manifestations of the same disease, the mode of clinical presentation and the extent of thrombosis may affect patient prognosis. Thus, patients with distal (calf) DVT have a $2.5 \%$ annual risk of recurrence after three months of anticoagulation, which is 2-to-4-fold lower than patients with proximal DVT and/or PE $[6,10,13 \bullet \bullet, 29,30 \bullet]$. Whereas some discrepant findings were reported for patients presenting with PE compared to patients presenting with DVT alone [12,31-33], two independent patient-level meta-analyses found no difference in rates of recurrent VTE, irrespective of initial presentation as DVT or PE $[13 \bullet \bullet, 30 \bullet]$. However, patients presenting with $\mathrm{PE}$ are more likely to develop recurrence manifesting as PE than as DVT $[12,30 \bullet, 32,33]$ and, consequently, are at increased risk that recurrence will be life-threatening or will lead to chronic pulmonary hypertension. The ACCP Guidelines recommend the same anticoagulant therapy management in patients presenting with PE or isolated proximal DVT [ $5 \bullet \bullet$.

\section{Hereditary thrombophilic defects}

The factor $\mathrm{V}$ Leiden and prothrombin gene mutations are the most common prothrombotic genetic abnormalities occurring in patients with VTE [34]. Deficiencies of endogenous anticoagulants (antithrombin, protein $\mathrm{C}$, protein S), high levels of factor VIII and XI, and hyperhomocysteinemia are other, less common, hereditary thrombophilic defects [34]. One or more of these abnormalities occur in up to $50 \%$ of patients with a first unprovoked VTE $[20,35,36]$ but there is a weak or non-significant association between these abnormalities and the development of recurrent VTE [35,37-46]. Prospective studies have not shown that testing for thrombophilia can predict the longterm risk of recurrent VTE, especially after adjusting for stronger predictors such as the absence of an antecedent provoking risk factor $[20,21]$, and no studies have shown that management strategies based on thrombophilia test- 
ing affect patients' risk for recurrence [47]. Furthermore, there is no known relation between a family history of VTE and the likelihood of detecting a thrombophilic abnormality [48]. For these reasons, routine screening for inherited thrombophilia is not recommended in patients with unprovoked VTE as it will not have a major impact on the duration of anticoagulation $[5 \bullet \bullet, 49,50]$. In selected patients testing for thrombophilia may assist in their counseling about prognosis, but the implications of the test results should be clearly discussed with patients before testing is done [49-51].

Laboratory testing for lupus anticoagulant, anticardiolipin antibodies and anti- $\alpha 2$ glycoprotein-I antibodies merits special consideration since usually they are not inherited abnormalities. It is difficult to estimate their prevalence in the general population because of the potential for false positive test results, especially when a positive test is not confirmed with repeat testing and at a time remote from the acute VTE [35,52-54]. The clinical significance of individual tests is uncertain, in part because of different laboratory assays and criteria for test positivity. However, in one well-designed study involving patients with prior VTE (who stopped anticoagulation), a positive anticardiolipin antibody or lupus anticoagulant conferred a 2-fold higher risk of recurrent VTE than patients with a negative test [55]. Overall, a diagnosis of the antiphospholipid syndrome should be made carefully, requiring the combination of clinical and laboratory criteria [56]. Moreover, positive laboratory tests should be confirmed with repeat testing done at least six weeks apart and at a time remote from the index VTE or other acute illnesses. If this diagnosis is confirmed, it has important clinical implications because of the high risk for recurrent VTE if anticoagulation is stopped.

\section{Residual vein occlusion}

In patients with proximal DVT, the presence of a residual vein occlusion (RVO) identified by venous ultrasound three or more months after diagnosis may identify patients at increased risk for recurrent VTE. Some studies found that patients with RVO, whether occlusive or non-occlusive, are at increased risk for recurrent VTE compared with patients in whom there is complete vein recanalization [57-59]. In three randomized trials [60-62] that explored the benefit of extended anticoagulation in patients with RVO after 36 months of anticoagulation for DVT found a higher rate of recurrence in patients with RVO than in those without RVO. On the other hand, a patient-level meta-analysis suggested that RVO was a weak predictor of recurrence after unprovoked VTE and that the association between RVO and recurrence was stronger if RVO was detected early (within three months) than later ( $>6$ months) after diagnosis [63]. The use of RVO to assess recurrence risk is limited by the lack of a standard definition for RVO and the potential for operator variability in the interpretation of ultrasound findings [64].

\section{D-dimer}

D-dimer, a fibrin degradation product, which is used to assess patients with suspected DVT or PE, has been also studied as a predictor of recurrent VTE when measured after the completion of 3-6 months of anticoagulation in 


\section{Clinical prediction guides for recurrent VTE}

patients with a first VTE. Individual studies [65-71] and meta-analyses $[16 \bullet, 72,73]$ found a 2 -fold higher risk of recurrence in patients with unprovoked VTE who had an elevated (or positive) post-anticoagulation D-dimer than in patients with a normal (or negative) D-dimer. Thus, a positive D-dimer conferred an almost $9 \%$ annual absolute risk for recurrent VTE (cumulative rate $30-35 \%$ after five years) after the index event [16 $\bullet$. A patient-level meta-analysis [16•] found that the prognostic utility of D-dimer was independent of patient age, timing of post-anticoagulation D-dimer testing, and the D-dimer cutpoint $(250$ or $500 \mathrm{ng} / \mathrm{mL}$ ) used to define a positive/negative test. In one study, D-dimer and RVO were jointly studied after stopping anticoagulation but only D-dimer was an independent predictor of recurrent VTE [74].

In patients with a positive post-anticoagulation D-dimer, resumption of anticoagulation should be considered given the associated higher risk for recurrent VTE [67]. In such circumstances an alternative approach is to repeat the D-dimer measurement so as to reduce the potential for spuriously elevated levels and to base decisions on long-term anticoagulation on consistently elevated D-dimer levels [75•]. Finally, there are limitations of D-dimer when used in this clinical circumstance [64]. Ideally, D-dimer as a determinant of recurrent VTE risk should be expressed as a continuous variable [76], but a cut-point that dichotomizes patients' risk for recurrent VTE (into low or high risk groups) might be more useful in clinical practice. The drawback of this approach is the potential need for assay-specific D-dimer cut-points [77]. In addition, even if the prognostic value of the D-dimer is independent of patient age and comorbidity [78], D-dimer levels are higher, on average, in the elderly [67] and age-specific D-dimer cut-points may increase its specificity [77]. Age-specific D-dimer cut-points, as proposed for the diagnostic use of D-dimer [79], may be helpful. Overall, additional research is needed to identify the optimal manner in which D-dimer can be used as a predictor of recurrent VTE.

Other global markers of coagulation activation, such as measures of thrombin generation, have been assessed as predictors of recurrent VTE, but are not yet ready for clinical use [80,81].

There are three CPGs that have been developed to stratify patients with treated unprovoked VTE as being at high or low risk for disease recurrence. The Men and HER-DOO-2 CPG was the first such guide that was derived from a prospective cohort of patients with a first unprovoked proximal DVT and/or PE [82]. With this CPG, all men are considered at high risk of recurrence (based on a $3 \%$ annual risk threshold to define high risk). For women, $\geq 2$ factors (comprising lower extremity hyperpigmentation, edema, redness, D-dimer $\geq 250 \mathrm{ng} / \mathrm{mL}$ [during anticoagulant therapy], obesity [body mass index $\geq 30 \mathrm{~kg} / \mathrm{m}^{2}$ ], and age over 65 years) identifies women at high risk for recurrent VTE, whereas $<2$ factors identifies women at low ( $<3 \%$ per year) risk for recurrence $[83 \bullet \bullet$. The Vienna CPG uses patient sex, VTE site/extension and D-dimer (post-anticoagulation) to estimate an individual patient's risk

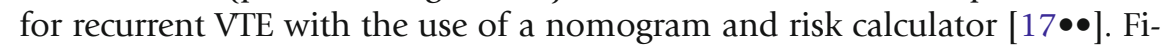
nally, the DASH CPG, which comprises D-dimer (post-anticoagulation), pa- 


\section{Conclusion}

tient age, patient sex, and VTE occurring in association with hormonal therapy, provides a numeric score corresponding to a risk for recurrent VTE based on these four factors $[84 \bullet \bullet$. Overall, although these CPGs may help clinicians in stratifying patients according to risk for recurrent VTE, they require independent validation in separate patient populations [85].

In this review, we summarized key clinical and laboratory factors that confer an increased risk for disease recurrence after a first unprovoked DVT or PE. CPGs have been developed which combine these factors so as to classify patients into high- or low-risk risk groups or to provide individualized estimates for recurrence risk.

The CPGs that are developed to quantify the risk for recurrent VTE are anchored on what is considered an 'acceptably low' rate of recurrence that would justify stopping anticoagulation after 3-6 months of treatment [86]. Based on data involving patients at low risk for recurrence (i.e., VTE provoked by a major risk factor), an annualized rate of approximately $3 \%$ patient-year [82] (or a risk of $5 \%$ at one year and $15 \%$ at five years [86]) has been proposed as a threshold below which most clinicians would consider the risk of recurrence acceptably low so as to justify stopping anticoagulation. Ideally, complementary CPGs should stratify patients according to their risk for bleeding if anticoagulation is continued. To date, few CPGs have estimated the anticoagulant-related risk of bleeding in patients with VTE $[87,88]$, and none addressed the risk during long-term treatment. Although CPGs are available to predict bleeding in patients with atrial fibrillation, such as the HAS-BLED score [89], these CPGs have been developed in generally older populations than those with VTE.

The predicted rates of recurrent VTE and clinically important (or major) bleeding should then be combined with an assessment of the clinical impact of such events, which can be expressed by the case-fatality. Thus, in a large systematic review, the case-fatality rate for major bleeding during the initial three months of anticoagulation for VTE was $11.3 \%$ whereas the case-fatality rate for recurrent VTE after at least 3 months of anticoagulant therapy was 3.6\% $[90,91,92 \bullet \bullet]$. Finally, these objective factors should be combined with individual patients' values and preferences regarding the need (or not) for ongoing anticoagulation in addition to practical factors such as treatment costs and feasibility of anticoagulant monitoring [51].

Irrespective of whether a decision is made to continue or stop anticoagulant therapy, such a decision should not be irreversible. Indeed, patients should be reassessed periodically to re-evaluate their risk profile, to reassess their preferences and to incorporate new research findings into individual patient management. For example, two recent randomized trials have shown that patients with unprovoked VTE who take low-dose ASA (100 mg daily) after completing anticoagulant therapy have a $25-30 \%$ reduction in the risk for recurrent VTE $[93,94 \bullet \bullet]$. Thus, ASA may be a long-term treatment option in patients at intermediate risk for recurrence or those at higher risk for anticoagulant-related bleeding. Additional prospective studies are needed to explore clinical management strategies which may include stopping 
anticoagulant therapy in patients at low risk, switching to ASA in patients at intermediate risk for recurrence, and continuing anticoagulants in patients at high risk for recurrent VTE.

\section{Disclosure}

No potential conflicts of interest relevant to this article were reported.

\section{Open Access}

This article is distributed under the terms of the Creative Commons Attribution License which permits any use, distribution, and reproduction in any medium, provided the original author(s) and the source are credited.

\section{References and Recommended Reading}

Papers of particular interest, published recently, have been highlighted as:

- Of importance

$\bullet \quad$ Of major importance

1. $\quad$ Kearon C. A conceptual framework for two phases of anticoagulant treatment of venous thromboembolism. J Thromb Haemost. 2012;10:507-11.

An interesting narrative review on the biphasic nature of venous thromboembolic disease and resultant treatment approach.

2. Naess IA, Christiansen SC, Romundstad P, Cannegieter SC, Rosendaal FR, Hammerstrom J. Incidence and mortality of venous thrombosis: a population-based study. J Thromb Haemost. 2007;5:692-9.

3. Goldhaber SZ. Pulmonary embolism. Lancet. 2004;363:1295-305.

4. Agnelli G, Becattini C. Acute pulmonary embolism. N Engl J Med. 2010;363:266-74.

5.• Kearon C, Akl EA, Comerota AJ, Prandoni P, Bounameaux H, Goldhaber SZ, Nelson ME, Wells PS, Gould MK, Dentali F, Crowther M, Kahn SR. Antithrombotic therapy for VTE disease: Antithrombotic Therapy and Prevention of Thrombosis, 9th ed: American College of Chest Physicians Evidence-Based Clinical Practice Guidelines. Chest. 2012;141:e419S-94S.

These guidelines are a synthesis of evidence for the short and long term treatment of venous thromboembolism. For patients with a first unprovoked event, the recommendations for the long-term management consider a three months or indefinite anticoagulation and also consider bleeding risk and patient values and preferences.

6. Hansson PO, Sorbo J, Eriksson H. Recurrent venous thromboembolism after deep vein thrombosis: incidence and risk factors. Arch Intern Med. 2000;160:769-74.
7. Kahn SR, Shrier I, Julian JA, Ducruet T, Arsenault L, Miron MJ, Roussin A, Desmarais S, Joyal F, Kassis J, Solymoss S, Desjardins L, Lamping DL, Johri M, Ginsberg JS. Determinants and time course of the postthrombotic syndrome after acute deep venous thrombosis. Ann Intern Med. 2008;149:698-707.

8. Piazza G, Goldhaber SZ. Chronic thromboembolic pulmonary hypertension. N Eng J Med. 2011;364:351-60.

9. Schulman S, Wahlander K, Lundstrom T, Clason SB, Eriksson $\mathrm{H}$. Secondary prevention of venous thromboembolism with the oral direct thrombin inhibitor ximelagatran. N Engl J Med. 2003;349:1713-21.

10. Schulman S, Rhedin AS, Lindmarker P, Carlsson A, Larfars G, Nicol P, Loogna E, Svensson E, Ljungberg B, Walter H. A comparison of six weeks with six months of oral anticoagulant therapy after a first episode of venous thromboembolism. Duration of Anticoagulation Trial Study Group. N Engl J Med. 1995;332:1661-5.

11. Agnelli G, Prandoni $P$, Santamaria MG, Bagatella $P$, Iorio A, Bazzan M, Moia M, Guazzaloca G, Bertoldi A, Tomasi C, Scannapieco G, Ageno W. Three months versus one year of oral anticoagulant therapy for idiopathic deep venous thrombosis. Warfarin Optimal Duration Italian Trial Investigators. N Engl J Med. 2001;345:165-9.

12. Agnelli G, Prandoni $P$, Becattini $C$, Silingardi $M$, Taliani MR, Miccio M, Imberti D, Poggio R, Ageno W, Pogliani E, Porro F, Zonzin P. Extended oral antico- 
agulant therapy after a first episode of pulmonary embolism. Ann Intern Med. 2003;139:19-25.

13.• Boutitie F, Pinede L, Schulman S, Agnelli G, Raskob G, Julian J, Hirsh J, Kearon C. Influence of preceding length of anticoagulant treatment and initial presentation of venous thromboembolism on risk of recurrence after stopping treatment: analysis of individual participants' data from seven trials. BMJ. 2011;342:d3036.

This meta-analysis compares different lengths of anticoagulation for venous thromboembolism, showing that three months of treatment results in a lower risk of recurrence compared to a shorter course but in a similar risk compared to a longer duration.

14. Schulman S, Beyth RJ, Kearon C, Levine MN. Hemorrhagic complications of anticoagulant and thrombolytic treatment: American College of Chest Physicians Evidence-Based Clinical Practice Guidelines (8th Edition). Chest. 2008;133:257S-98S.

15.• Iorio A, Kearon C, Filippucci E, Marcucci M, Macura A, Pengo V, Siragusa S, Palareti G. Risk of recurrence after a first episode of symptomatic venous thromboembolism provoked by a transient risk factor: a systematic review. Arch Intern Med. 2010;170:1710-6.

This meta-analysis considers the risk of recurrence in patients with provoked venous thromboembolism, whether related to surgical and nonsurgical transient risk factors.

16. Douketis J, Tosetto A, Marcucci M, Baglin T, Cushman M, Eichinger S, Palareti G, Poli D, Tait RC, Iorio A. Patientlevel meta-analysis: effect of measurement timing, threshold, and patient age on ability of D-dimer testing to assess recurrence risk after unprovoked venous thromboembolism. Arch Intern Med. 2010;153:523-31. This patient level meta-analysis provides further support for the D-dimer as predictor of recurrent venous thromboembolism, irrespective of the timing of testing after stopping anticoagulation, the assay used and the patient age.

17.• Eichinger S, Heinze G, Jandeck LM, Kyrle PA. Risk assessment of recurrence in patients with unprovoked deep vein thrombosis or pulmonary embolism: the Vienna prediction model. Circulation. 2010;121:1630-6.

This study provides a clinical prediction guide for the risk of recurrence in patient with a first unprovoked venous thromboembolism based on clinical and laboratory risk factors.

18. Prandoni P, Noventa F, Ghirarduzzi A, Pengo V, Bernardi E, Pesavento R, Iotti M, Tormene D, Simioni $\mathrm{P}$, Pagnan A. The risk of recurrent venous thromboembolism after discontinuing anticoagulation in patients with acute proximal deep vein thrombosis or pulmonary embolism. A prospective cohort study in 1,626 patients. Haematologica. 2007;92:199-205.

19. Rosendaal FR, Helmerhorst FM, Vandenbroucke JP. Female hormones and thrombosis. Arterioscler Thromb Vasc Biol. 2002;22:201-10.

20. Christiansen SC, Cannegieter SC, Koster T, Vandenbroucke JP, Rosendaal FR. Thrombophilia, clinical factors, and recurrent venous thrombotic events. JAMA. 2005;293:2352-61.

21. Baglin T, Luddington R, Brown $K$, Baglin C. Incidence of recurrent venous thromboembolism in relation to clinical and thrombophilic risk factors: prospective cohort study. Lancet. 2003;362:523-6.

22. Cushman M, Glynn RJ, Goldhaber SZ, Moll S, Bauer KA, Deitcher S, Shrivastava S, Ridker PM. Hormonal factors and risk of recurrent venous thrombosis: the prevention of recurrent venous thromboembolism trial. J Thromb Haemost. 2006;4:2199-203.

23.• Douketis J, Tosetto A, Marcucci M, Baglin T, Cosmi B, Cushman M, Kyrle P, Poli D, Tait RC, Iorio A. Risk of recurrence after venous thromboembolism in men and women: patient level meta-analysis. BMJ. 2011;342:d813.

This patient data meta-analysis supports the higher risk of recurrence after a first unprovoked venous thromboembolism in men compared to women.

24. Kyrle PA, Minar E, Bialonczyk C, Hirschl M, Weltermann A, Eichinger S. The risk of recurrent venous thromboembolism in men and women. N Engl J Med. 2004;350:2558-63.

25. Agnelli G, Becattini C, Prandoni P. Recurrent venous thromboembolism in men and women. $\mathrm{N}$ Engl J Med. 2004;351:2015-8.

26. Nieto JA, Monreal M. Recurrent venous thromboembolism in men and women. N Engl J Med. 2004;351:2015-8.

27. Kahn SR. Recurrent venous thromboembolism in men and women. N Engl J Med. 2004;351:2015-8.

28. McRae S, Tran H, Schulman S, Ginsberg J, Kearon C. Effect of patient's sex on risk of recurrent venous thromboembolism: a meta-analysis. Lancet. 2006;368:371-8.

29. Hull R, Delmore T, Genton E, Hirsh J, Gent M, Sackett D, McLoughlin D, Armstrong P. Warfarin sodium versus low-dose heparin in the long-term treatment of venous thrombosis. $\mathrm{N}$ Engl J Med. 1979;301:855-8.

30. Baglin T, Douketis J, Tosetto A, Marcucci M, Cushman M, Kyrle P, Palareti G, Poli D, Tait RC, Iorio A. Does the clinical presentation and extent of venous thrombosis predict likelihood and type of recurrence? A patient-level meta-analysis. J Thromb Haemost. 2010;8:2436-42.

This patient data meta-analysis supports a comparable risk of recurrence in patients presenting with a pulmonary embolism or proximal deep vein thrombosis and that patients presenting with pulmonary embolism are more likely to develop recurrent disease manifest by pulmonary embolism.

31. Eichinger S, Weltermann A, Minar E, Stain M, Schonauer V, Schneider B, Kyrle PA. Symptomatic pulmonary embolism and the risk of recurrent venous thromboembolism. Arch Intern Med. 2004;164:92-6.

32. Douketis JD, Gu CS, Schulman S, Ghirarduzzi A, Pengo V, Prandoni P. The risk for fatal pulmonary embolism after discontinuing anticoagulant therapy for venous thromboembolism. Ann Intern Med. $2007 ; 147: 766-74$. 
33. Murin S, Romano PS, White RH. Comparison of outcomes after hospitalization for deep venous thrombosis or pulmonary embolism. Thromb Haemost. 2002;88:407-14.

34. Seligsohn U, Lubetsky A. Genetic susceptibility to venous thrombosis. N Engl J Med. 2001;344:1222-31.

35. Middeldorp S, Van Hylckama Vlieg A. Does thrombophilia testing help in the clinical management of patients? Br J Haematol. 2008;143:321-35.

36. Kyrle PA, Rosendaal FR, Eichinger S. Risk assessment for recurrent venous thrombosis. Lancet.

2010;376:2032-9.

37. Kearon C, Ginsberg JS, Anderson DR, Kovacs MJ, Wells P, Julian JA, Mackinnon B, Demers C, Douketis J, Turpie AG, Van Nguyen P, Green D, Kassis J, Kahn SR, Solymoss S, Desjardins L, Geerts W, Johnston M, Weitz JI, Hirsh J, Gent M. Comparison of 1 month with 3 months of anticoagulation for a first episode of venous thromboembolism associated with a transient risk factor. J Thromb Haemost. 2004;2:743-9.

38. Eichinger S, Pabinger I, Stumpflen A, Hirschl M, Bialonczyk C, Schneider B, Mannhalter C, Minar E, Lechner K, Kyrle PA. The risk of recurrent venous thromboembolism in patients with and without factor V Leiden. Thromb Haemost. 1997;77:624-8.

39. Eichinger S, Minar E, Hirschl M, Bialonczyk C, Stain M, Mannhalter C, Stumpflen A, Schneider B, Lechner $\mathrm{K}$, Kyrle PA. The risk of early recurrent venous thromboembolism after oral anticoagulant therapy in patients with the G20210A transition in the prothrombin gene. Thromb Haemost. 1999;81:14-7.

40. Simioni P, Prandoni P, Lensing AW, Scudeller A, Sardella C, Prins MH, Villalta S, Dazzi F, Girolami A. The risk of recurrent venous thromboembolism in patients with an Arg506->Gln mutation in the gene for factor V (factor V Leiden). N Engl J Med. 1997;336:399-403.

41. Simioni P, Prandoni $\mathrm{P}$, Lensing AW, Manfrin D, Tormene D, Gavasso S, Girolami B, Sardella C, Prins M, Girolami A. Risk for subsequent venous thromboembolic complications in carriers of the prothrombin or the factor $\mathrm{V}$ gene mutation with a first episode of deep-vein thrombosis. Blood. 2000;96:3329-33.

42. van den Belt AG, Sanson BJ, Simioni P, Prandoni P, Buller HR, Girolami A, Prins MH. Recurrence of venous thromboembolism in patients with familial thrombophilia. Arch Intern Med. 1997;157:2227-32.

43. De Stefano V, Simioni P, Rossi E, Tormene D, Za T, Pagnan A, Leone G. The risk of recurrent venous thromboembolism in patients with inherited deficiency of natural anticoagulants antithrombin, protein $\mathrm{C}$ and protein S. Haematologica. 2006;91:695-8.

44. Brouwer JL, Lijfering WM, Ten Kate MK, Kluin-Nelemans $\mathrm{HC}$, Veeger NJ, van der Meer J. High long-term absolute risk of recurrent venous thromboembolism in patients with hereditary deficiencies of protein S, protein C or antithrombin. Thromb Haemost. 2009;101:93-9.

45. Ho WK, Hankey GJ, Quinlan DJ, Eikelboom JW. Risk of recurrent venous thromboembolism in patients with common thrombophilia: a systematic review. Arch Intern Med. 2006;166:729-36.

46. Marchiori A, Mosena L, Prins MH, Prandoni P. The risk of recurrent venous thromboembolism among heterozygous carriers of factor $\mathrm{V}$ Leiden or prothrombin G20210A mutation. A systematic review of prospective studies. Haematologica. 2007;92:1107-14.

47. Cohn D, Vansenne F, de BC, Middeldorp S.Thrombophilia testing for prevention of recurrent venous thromboembolism. Cochrane Database Syst Rev. 2009,CD007069.

48. Cosmi B, Legnani C, Bernardi F, Coccheri S, Palareti $\mathrm{G}$. Role of family history in identifying women with thrombophilia and higher risk of venous thromboembolism during oral contraception. Arch Intern Med. 2003;163:1105-9.

49. Pernod G, Biron-Andreani C, Morange PE, Boehlen F, Constans J, Couturaud F, Drouet L, Jude B, Lecompte T, Le GG, Trillot N, Wahl D. Recommendations on testing for thrombophilia in venous thromboembolic disease: a French consensus guideline. J Mal Vasc. 2009;34:156-203.

50. Baglin T, Gray E, Greaves M, Hunt BJ, Keeling D, Machin S, Mackie I, Makris M, Nokes T, Perry D, Tait RC, Walker I, Watson H. Clinical guidelines for testing for heritable thrombophilia. Br J Haematol. 2010;149:209-20.

51. MacLean S, Mulla S, Akl EA, Jankowski M, Vandvik PO, Ebrahim S, McLeod S, Bhatnagar N, Guyatt GH. Patient values and preferences in decision making for antithrombotic therapy: a systematic review: Antithrombotic Therapy and Prevention of Thrombosis, 9th ed: American College of Chest Physicians Evidence-Based Clinical Practice Guidelines. Chest. 2012;141:e1S-e23S.

52. Runchey SS, Folsom AR, Tsai MY, Cushman M, McGovern PD. Anticardiolipin antibodies as a risk factor for venous thromboembolism in a population-based prospective study. Br J Haematol. 2002;119:1005-10.

53. de Groot PG, Lutters B, Derksen RH, Lisman T, Meijers JC, Rosendaal FR. Lupus anticoagulants and the risk of a first episode of deep venous thrombosis. J Thromb Haemost. 2005;3:1993-7.

54. Naess IA, Christiansen SC, Cannegieter SC, Rosendaal FR, Hammerstroem J. A prospective study of anticardiolipin antibodies as a risk factor for venous thrombosis in a general population (the HUNT study). J Thromb Haemost. 2006;4:44-9.

55. Schulman S, Svenungsson E, Granqvist S. Anticardiolipin antibodies predict early recurrence of 
thromboembolism and death among patients with venous thromboembolism following anticoagulant therapy. Duration of Anticoagulation Study Group. Am J Med. 1998;104:332-8.

56. Miyakis S, Lockshin MD, Atsumi T, Branch DW, Brey RL, Cervera R, Derksen RH, de Groot PG, Koike T, Meroni PL, Reber G, Shoenfeld Y, Tincani A, Vlachoyiannopoulos PG, Krilis SA. International consensus statement on an update of the classification criteria for definite antiphospholipid syndrome (APS). J Thromb Haemost. 2006;4:295-306.

57. Piovella F, Crippa L, Barone M, Vigano DS, Serafini S, Galli L, Beltrametti C, D'Angelo A. Normalization rates of compression ultrasonography in patients with a first episode of deep vein thrombosis of the lower limbs: association with recurrence and new thrombosis. Haematologica. 2002;87:515-22.

58. Prandoni $\mathrm{P}$, Lensing AW, Prins $\mathrm{MH}$, Bernardi E, Marchiori A, Bagatella P, Frulla M, Mosena L, Tormene D, Piccioli A, Simioni P, Girolami A. Residual venous thrombosis as a predictive factor of recurrent venous thromboembolism. Ann Intern Med. 2002;137:955-60.

59. Young L, Ockelford P, Milne D, Rolfe-Vyson V, Mckelvie S, Harper P. Post-treatment residual thrombus increases the risk of recurrent deep vein thrombosis and mortality. J Thromb Haemost. 2006;4:1919-24.

60. Siragusa S, Malato A, Anastasio R, Cigna V, Milio G, Amato C, Bellisi M, Attanzio MT, Cormaci O, Pellegrino M, Dolce A, Casuccio A, Bajardi G, Mariani G. Residual vein thrombosis to establish duration of anticoagulation after a first episode of deep vein thrombosis: the Duration of Anticoagulation based on Compression UltraSonography (DACUS) study. Blood. 2008;112:511-5.

61. Prandoni P, Prins $\mathrm{MH}$, Lensing AW, Ghirarduzzi A, Ageno W, Imberti D, Scannapieco G, Ambrosio GB, Pesavento R, Cuppini S, Quintavalla R, Agnelli G. Residual thrombosis on ultrasonography to guide the duration of anticoagulation in patients with deep venous thrombosis: a randomized trial. Ann Intern Med. 2009; 150:577-85.

62. Siragusa S, Malato A, Saccullo G, Iorio A, Di IM, Caracciolo C, Coco LL, Raso S, Santoro M, Guarneri FP, Tuttolomondo A, Pinto A, Pepe I, Casuccio A, Abbadessa V, Licata G, Battista RG, Mariani G, Di FG. Residual vein thrombosis for assessing duration of anticoagulation after unprovoked deep vein thrombosis of the lower limbs: the extended DACUS study. Am J Hematol. 2011;86:914-7.

63. Douketis, J. (Personal Communication, November, 2012).

64. Malato A, Saccullo G, Iorio A, Ageno W, Siragusa S. Residual vein thrombosis and D-dimer for optimizing duration of anticoagulation in idiopathic deep vein thrombosis. Curr Pharm Des. 2010;16:3483-6.
65. Palareti G, Legnani C, Cosmi B, Valdre L, Lunghi B, Bernardi F, Coccheri S. Predictive value of D-dimer test for recurrent venous thromboembolism after anticoagulation withdrawal in subjects with a previous idiopathic event and in carriers of congenital thrombophilia. Circulation. 2003;108:313-8.

66. Eichinger S, Minar E, Bialonczyk C, Hirschl M, Quehenberger P, Schneider B, Weltermann A, Wagner $\mathrm{O}$, Kyrle PA. D-dimer levels and risk of recurrent venous thromboembolism. JAMA. 2003;290:1071-4.

67. Palareti G, Cosmi B, Legnani C, Tosetto A, Brusi C, Iorio A, Pengo V, Ghirarduzzi A, Pattacini C, Testa S, Lensing AW, Tripodi A. D-dimer testing to determine the duration of anticoagulation therapy. $\mathrm{N}$ Engl J Med. 2006;355:1780-9.

68. Shrivastava S, Ridker PM, Glynn RJ, Goldhaber SZ, Moll S, Bounameaux H, Bauer KA, Kessler CM, Cushman M. D-dimer, factor VIII coagulant activity, low-intensity warfarin and the risk of recurrent venous thromboembolism. J Thromb Haemost. 2006;4:1208-14.

69. Tait RC, Lowe GD, McColl MD, MacMahon AD, Robertson L, King L. Predicting risk of recurrent venous thrombosis using a 5-point scoring system including fibrin D-dimer. J Thromb Haemost. 2007;2:1873-8.

70. Poli D, Antonucci E, Ciuti G, Abbate R, Prisco D. Combination of D-dimer, F1 + 2 and residual vein obstruction as predictors of VTE recurrence in patients with first VTE episode after OAT withdrawal. J Thromb Haemost. 2008;6:708-10.

71. Baglin T, Palmer CR, Luddington R, Baglin C. Unprovoked recurrent venous thrombosis: prediction by D-dimer and clinical risk factors. J Thromb Haemost. 2008;6:577-82.

72. Verhovsek M, Douketis JD, Yi Q, Shrivastava S, Tait RC, Baglin T, Poli D, Lim W. Systematic review: Ddimer to predict recurrent disease after stopping anticoagulant therapy for unprovoked venous thromboembolism. Ann Intern Med. 2008;149:481-90.

73. Bruinstroop E, Klok FA, Van De Ree MA, Oosterwijk FL, Huisman MV. Elevated D-dimer levels predict recurrence in patients with idiopathic venous thromboembolism: a meta-analysis. J Thromb Haemost. 2009;7:611-8.

74. Cosmi B, Legnani C, Cini M, Guazzaloca G, Palareti G. $\mathrm{D}$-dimer levels in combination with residual venous obstruction and the risk of recurrence after anticoagulation withdrawal for a first idiopathic deep vein thrombosis. J Thromb Haemost. 2005;94:969-74.

75. Cosmi B, Legnani C, Tosetto A, Pengo V, Ghirarduzzi A, Testa S, Prisco D, Poli D, Tripodi A, Marongiu F, Palareti G. Usefulness of repeated D-dimer testing after stopping anticoagulation for a first episode of unprovoked venous thromboembolism: the PROLONG II prospective study. Blood. 2010;115:481-8 
This study shows that repeat post-anticoagulation D-dimer testing may help to better distinguish patients with a high or low risk of recurrent venous thromboembolism.

76. Altman DG, Lausen B, Sauerbrei W, Schumacher M. Dangers of using "optimal" cutpoints in the evaluation of prognostic factors. J Natl Cancer Inst.

1994;86:829-35.

77. Legnani C, Cini M, Cosmi B, Carraro P, Tripodi A, Erba N, Palareti G. Age and gender specific cut-off values to improve the performance of $\mathrm{D}$ : -dimer assays to predict the risk of venous thromboembolism recurrence. Intern Emerg Med. 2011.

78. Cosmi B, Legnani C, Tosetto A, Pengo V, Ghirarduzzi A, Testa S, Prisco D, Poli D, Tripodi A, Palareti G. Comorbidities, alone and in combination with $\mathrm{D}$ dimer, as risk factors for recurrence after a first episode of unprovoked venous thromboembolism in the extended follow-up of the PROLONG study. Thromb Haemost. 2010;103:1152-60.

79. Douma RA, Le GG, Sohne M, Righini M, Kamphuisen PW, Perrier A, Kruip MJ, Bounameaux H, Buller HR, Roy PM. Potential of an age adjusted D-dimer cut-off value to improve the exclusion of pulmonary embolism in older patients: a retrospective analysis of three large cohorts. BMJ. 2010;340:c1475.

80. Hron G, Kollars M, Binder BR, Eichinger S, Kyrle PA. Identification of patients at low risk for recurrent venous thromboembolism by measuring thrombin generation. JAMA. 2006;296:397-402.

81. Besser M, Baglin C, Luddington R, Van HV. Baglin T. High rate of unprovoked recurrent venous thrombosis is associated with high thrombin-generating potential in a prospective cohort study. J Thromb Haemost. 2008;6:1720-5.

82. Rodger MA, Kahn SR, Wells PS, Anderson DA, Chagnon I, Le GG, Solymoss S, Crowther M, Perrier A, White R, Vickars L, Ramsay T, Betancourt MT, Kovacs MJ. Identifying unprovoked thromboembolism patients at low risk for recurrence who can discontinue anticoagulant therapy. CMAJ. 2008;179:417-26.

83.• Le Gal G, Kovacs MJ, Carrier M, Do K, Kahn SR, Wells PS, Anderson DA, Chagnon I, Solymoss S, Crowther M, Righini M, Lacut K, White RH, Vickars L, Rodger $M$. Risk of recurrent venous thromboembolism after a first oestrogen-associated episode. Data from the REVERSE cohort study. Thromb Haemost. 2010;104:498-503.

This study represents the first attempt of building a clinical prediction guide based on clinical and laboratory risk factors with the aim of identifying patients with a risk of venous thromboembolic recurrence below or above an "acceptable" rate.

84.• Tosetto A, Iorio A, Marcucci M, Baglin T, Cushman M, Eichinger S, Palareti G, Poli D, Tait RC, Douketis J. Predicting disease recurrence in patients with previous unprovoked venous thromboembolism: a proposed prediction score (DASH). J Thromb Haemost. 2012;10:1019-25.

This study provides a clinical prediction guide to estimate recurrence risk in patients with unprovoked venous thromboembolism who have received approximately six months of anticoagulant therapy.

85. Moons KG, Royston P, Vergouwe Y, Grobbee DE, Altman DG. Prognosis and prognostic research: what, why, and how? BMJ. 2009;338:b375.

86. Kearon C, Iorio A, Palareti G. Risk of recurrent venous thromboembolism after stopping treatment in cohort studies: recommendation for acceptable rates and standardized reporting. J Thromb Haemost. 2010;8:2313-5.

87. Kuijer PM, Hutten BA, Prins MH, Büller HR. Prediction of the risk of bleeding during the anticoagulant treatment for venous thromboembolism. Arch Intern Med. 1999;159:457-60.

88. Ruíz-Giménez N, Suárez C, González R, Nieto JA, Todolí JA, Samperiz AL, Monreal M, RIETE Investigators. Predictive variables for major bleeding events in patients presenting with documented acute venous thromboembolism. Findings from the RIETE Registry. Thromb Haemost. 2008;100:26-31.

89. Pisters R, Lane DA, Nieuwlaat R, de Vos CB, Crijns HJ, Lip GY. A novel user-friendly score (HAS-BLED) to assess 1year risk of major bleeding in patients with atrial fibrillation: the Euro Heart Survey. Chest. 2010;138:1093-100.

90. Douketis JD, Kearon C, Bates S, Duku EK, Ginsberg JS. Risk of fatal pulmonary embolism in patients with treated venous thromboembolism. JAMA. 1998;279:458-62.

91. Linkins LA, Choi PT, Douketis JD. Clinical impact of bleeding in patients taking oral anticoagulant therapy for venous thromboembolism: a meta-analysis. Ann Intern Med. 2003;139:893-900.

92.•• Carrier M, Le GG, Wells PS, Rodger MA. Systematic review: case-fatality rates of recurrent venous thromboembolism and major bleeding events among patients treated for venous thromboembolism. Ann Intern Med. 2010;152:578-89.

This study compares the clinical burden due to venous thromboembolic recurrences with that due to anticoagulantrelated bleeding in terms of case fatality rate.

93. Becattini C, Agnelli G, Schenone A, Eichinger S, Bucherini E, Silingardi M, Bianchi M, Moia M, Ageno W, Vandelli MR, Grandone E, Prandoni P. Aspirin for preventing the recurrence of venous thromboembolism. N Engl J Med. 2012;366:1959-67.

94.• Brighton TA, Eikelboom JW, Mann K, Mister R, Gallus A, Ockelford P, Gibbs H, Hague W, Xavier D, Diaz R, Kirby A, Simes J. Low-Dose Aspirin for Preventing Recurrent Venous Thromboembolism. N Engl J Med. 2012.

This and the previous study provide evidence on the efficacy of aspirin, given after a first course of anticoagulant, in re- 
ducing the risk of venous thromboembolic recurrence of 25$30 \%$ over 2-4 years of follow up.

95. Holbrook A, Schulman S, Witt DM, Vandvik PO, Fish J, Kovacs MJ, Svensson PJ, Veenstra DL, Crowther M, Guyatt GH. Evidence-based management of anticoagulant therapy: Antithrombotic Therapy and Prevention of Thrombosis, 9th ed: American College of Chest Physicians Evidence-Based Clinical Practice Guidelines. Chest. 2012;141:e152S-84S.

96. Andras A, Sala TA, Crawford F. Vitamin K antagonists or low-molecular-weight heparin for the long term treatment of symptomatic venous thromboembolism. Cochrane Database Syst Rev. 2012, 10:CD002001.

97. EINSTEIN Investigators, Bauersachs R, Berkowitz SD, Brenner B, Buller HR, Decousus H, Gallus AS, Lensing AW, Misselwitz F, Prins MH, Raskob GE, Segers A, Verhamme P, Wells P, Agnelli G, Bounameaux H, Cohen A, Davidson BL, Piovella F, Schellong S. Oral rivaroxaban for symptomatic venous thromboembolism. N Engl J Med. 2010;363:2499-510.

98. Buller HR, Prins MH, Lensin AW, Decousus H, Jacobson BF, Minar E, Chlumsky J, Verhamme P, Wells P, Agnelli G, Cohen A, Berkowitz SD, Bounameaux H, Davidson BL, Misselwitz F, Gallus AS, Raskob GE, Schellong S, Segers A. Oral rivaroxaban for the treatment of symptomatic pulmonary embolism. N Engl J Med. 2012;366:1287-97.

99. Schulman $\mathrm{S}$. Treatment of venous thromboembolism with dabigatran. Curr Opin Pulm Med. 2012;18:410-5.

100. Le GG, Kovacs MJ, Carrier M, Do K, Kahn SR, Wells PS, Anderson DA, Chagnon I, Solymoss S, Crowther M, Righini M, Lacut K, White RH, Vickars L, Rodger $M$. Risk of recurrent venous thromboembolism after a first oestrogen-associated episode. Data from the REVERSE cohort study. Thromb Haemost. 2010;104:498-503. 